\title{
Influence of ensiling time and inoculation on alteration of the starch-protein matrix in high-moisture corn
}

\author{
P. C. Hoffman, ${ }^{11}$ N. M. Esser, ${ }^{\star}$ R. D. Shaver, ${ }^{\star}$ W. K. Coblentz,† M. P. Scott, $\ddagger$ A. L. Bodnar, $§$ \\ R. J. Schmidt,\# and R. C. Charley\# \\ *Department of Dairy Science, University of Wisconsin, Madison 53706 \\ †US Dairy Forage Research Center, Madison, WI 53706 \\ fUSDA-ARS, Corn Insects and Crop Genetics Research Unit, Ames 50011 \\ §Interdepartmental Genetics, lowa State University, Ames 50011 \\ \#Lallemand Animal Nutrition, Milwaukee, WI 53218
}

\begin{abstract}
The fates of hydrophobic zein proteins, which encapsulate corn starch to create vitreous endosperm, have not been investigated in high-moisture corn (HMC). To assess influences of ensiling time and inoculation on zein proteins in HMC, quadruplicate samples of 2 random corn hybrids (A and B), containing 25.7 and $29.3 \%$ moisture, were ground, inoculated with (I) or without 600,000 cfu/g of Lactobacillus buchneri 40788 (Lallemand Animal Nutrition, Milwaukee, WI), and ensiled for $0,15,30,60,120$, and $240 \mathrm{~d}$. Nutrient composition [crude protein $(\mathrm{CP})$, starch, acid detergent fiber, and neutral detergent fiber], fermentation ( $\mathrm{pH}$, lactate, and acetate), and protein degradation markers (buffersoluble $\mathrm{CP}$, isopropanol-soluble $\mathrm{CP}$, and $\mathrm{NH}_{3}-\mathrm{N}$ ) were evaluated. At 0 and $240 \mathrm{~d}, \alpha, \gamma, \delta$, and $\beta$ zein subunits were profiled using HPLC. Data were evaluated as a split-split plot using the PROC MIXED procedures of SAS. Ensiling time and inoculation decreased $\mathrm{pH}$, and altered lactate and acetate contents of HMC. Lactate and acetate contents of $\mathrm{A}, \mathrm{AI}, \mathrm{B}$, and $\mathrm{BI}$ at $240 \mathrm{~d}$ were $0.40,0.32,1.11,0.73$, and $0,0.35,0.30$, and $0.87 \%$ of $\mathrm{DM}$, respectively. Buffer-soluble CP in HMC increased from 1.5 to $2.0 \%$ of $\mathrm{DM}$ at $0 \mathrm{~d}$ to $>4.0 \%$ of $\mathrm{DM}$ at 240 d. Inoculation had no effect on buffer-soluble CP but increased $\mathrm{NH}_{3}-\mathrm{N}$ content of HMC. Corn A contained more isopropanol-soluble CP than did corn B and peak areas for $6 \alpha$, and all $\gamma$ and $\delta$ zein regions were greater for corn A. Ensiling (0 vs. 240 d) decreased all zein subunits with the exception of $2 \alpha$ and $1 \delta$ subunit. Ensiling decreased $(42.2-73.2 \%) \gamma$ zeins, which are primarily responsible for cross-linking in the starch-protein matrix. Despite altering lactate and acetate contents, inoculation had no effect on degrading hydrophobic zein proteins in HMC. Data suggest that hydrophobic
\end{abstract}

Received June 23, 2010.

Accepted November 21, 2010

${ }^{1}$ Corresponding author: pchoffma@wisc.edu zein proteins in the starch-protein matrix of HMC are degraded by proteolytic activity over an extended ensiling time.

Key words: zein, high-moisture corn, inoculant

\section{INTRODUCTION}

The starch-protein matrix in corn has been defined previously as a physiochemical impediment to starch digestion in ruminants (Owens et al., 1986). In corn, hydrophobic zein proteins are the primary proteins in the starch-protein matrix, and comprise 50 to $60 \%$ of the total protein in whole corn (Hamaker et al., 1995). Zein proteins are classified as prolamins, consisting of 4 subclasses $(\alpha, \beta, \gamma, \delta)$, and are synthesized on the rough endoplasmic reticulum of the amyloplast (starch-producing organelle; Buchanan et al., 2000). Zein proteins are not intrinsic within the starch granule but are primarily surface localized on the exterior of starch granules (Mu-Forster and Wasserman, 1998). As zein proteins develop and distend with advancing maturity, $\beta$ - and $\gamma$-zeins cross-link and $\alpha$ - and $\delta$-zeins penetrate their network, thereby encapsulating starch into a hydrophobic starch-protein matrix (Mu-Forster and Wasserman, 1998; Buchanan et al., 2000).

Extensive cross-linking of zein proteins yields vitreous endosperm, and dry corn varieties with greater percentages of vitreous endosperm have decreased in vitro or in situ starch degradability (Philippeau et al., 2000; Correa et al., 2002; Ngonyamo-Majee et al., 2008). Feeding dry corn with greater vitreousness also decreased in vivo starch digestion in lactating dairy cows (Allen et al., 2008; Lopes et al., 2009). Detailed information on the fate of hydrophobic zein proteins, which impede starch digestion in ruminants during the ensiling process of high-moisture corn (HMC), is largely unknown.

Similar to responses observed commonly within ensiled forages, proteolysis degrades proteins in the HMC fermentation process (Baron et al., 1986). Philippeau and Michalet-Doreau, (1998) observed that ensiling 
grains increased ruminal starch degradability and hypothesized that ensiling increases accessibility of starch granules to rumen microorganisms, because hydrophobic zein proteins were degraded. Likewise, Jurjanz and Monteils (2005) observed ruminal degradability of starch to be greater for corn kernels after ensiling (92.3\%) as compared with that of unensiled corn kernels (70.2\%). The ensiling process improved starch degradation by increasing the rapidly degradable starch fraction $(80.7$ vs. $65.6 \%)$ and the starch degradation rate (12.4 vs. $8.0 \% / \mathrm{h}$ ). Combined, these data (Baron et al., 1986; Philippeau and Michalet-Doreau, 1998; Jurjanz and Monteils, 2005) yield a mechanistic hypothesis as to why greater ruminal and total-tract starch digestibility is observed for HMC compared with the digestibility of dry corn (Firkins et al., 2001). It was the objective of this project to determine the effects of ensiling time and bacterial inoculation on the fate of hydrophobic zein proteins in the starch-protein matrix of HMC.

\section{MATERIALS AND METHODS}

\section{Study Design}

This research was designed as a study of HMC chemistry to aid future animal trials investigating factors associated with HMC starch digestibility that may include ensiling, maturity, hybrid, particle size, or any of their many interactions. As a result, 2 random HMC were ensiled with and without an inoculant for 0,15 , $30,60,120$, or $240 \mathrm{~d}$ in an attempt to yield divergent HMC fermentations, while maintaining a manageable sample population.

On the day of HMC harvest, postprocessing but before ensiling, 2 corn hybrids (A and B) from 2 local Wisconsin dairy farms were procured. High-moisture corn varieties $\mathrm{A}$ and $\mathrm{B}$ were both ground with a similar hammer mill (DuraTech Industries International Inc., Jamestown, ND) fitted with a $0.79-\mathrm{cm}$ screen. Corn, as ground on the individual dairy farm, were divided into two 25-kg subsamples, with one subsample inoculated (I) with $600,000 \mathrm{cfu} / \mathrm{g}$ of Lactobacillus buchneri 40788 (Lallemand Inc., Milwaukee, WI). Quadruplicate samples $( \pm 1 \mathrm{~kg})$ of $\mathrm{A}, \mathrm{AI}, \mathrm{B}$, and $\mathrm{BI}$ were vacuum sealed in plastic bags and ensiled for $0,15,30,60,120$, or $240 \mathrm{~d}$ at $22^{\circ} \mathrm{C}$. Upon completion of the allotted ensiling time, HMC samples were frozen at $-18^{\circ} \mathrm{C}$ pending subsequent chemical analysis. Samples ensiled for $240 \mathrm{~d}$ were likewise frozen for $21 \mathrm{~d}$ to ensure protocol continuity.

\section{Laboratory Analysis}

After $261 \mathrm{~d}$, all samples were allowed to thaw and a 50-g subsample of each replicate of A, AI, B, and
BI for each ensiling interval was removed, placed in individual plastic bags, packed collectively in ice and sent in native form to Dairyland Laboratories (Arcadia, WI) for the determination of $\mathrm{pH}$ and concentrations of lactate, acetate, butyrate, propionate, and $\mathrm{NH}_{3}-\mathrm{N}$ (Muck and Dickerson, 1988). A second 100-g subsample was dried for $48 \mathrm{~h}$ in a forced-air oven, followed by drying $1 \mathrm{~g}$ at $105^{\circ} \mathrm{C}$ for $3 \mathrm{~h}$ to determined DM content. Mean particle size (MPS) for the dried subsample was determined by the procedures of Baker and Herrman (2002), and then the sample was milled through a Wiley mill (Arthur H. Thomas Co., Philadelphia, PA) fitted with a 1-mm screen. The samples were analyzed for CP (AOAC, 1990), starch (Ehrman, 1996), as well as $\mathrm{ADF}$ and NDF content by the methods of Goering and Van Soest (1970), with modifications described by Mertens (1992).

Protein fraction markers were determined for each sample, including borate-phosphate buffer-soluble CP (SCP; Krishnamoorthy et al., 1983), and isopropanol (PrOH) SCP (Larson and Hoffman, 2008), which is an estimate of total zein content. Concentrations of $\mathrm{N}$ in $\mathrm{ADF}$ and NDF, expressed on a CP basis (ADICP or NDICP), were ascertained by refluxing samples in neutral or acid detergent in an Ankom 200 fiber analyzer (Fairport, NY) as defined by Coblentz and Hoffman, (2009). The residual CP concentration within the respective residues was determined by a combustion technique (AOAC, 1998). No sodium sulfite was used in the NDF procedure to avoid removal of CP from the NDF residues (Van Soest et al., 1991).

Potential physical alteration of HMC induced by fermentation across ensiling days was evaluated using the near-infrared reflectance spectroscopy (NIRS) baseline shift (BLS), (Hoffman et al., 2010). The BLS of NIRS has been demonstrated to be a rapid measure of physical hardness or grinding efficiency (Hoffman et al., 2010). The BLS of NIRS is based on simple applications of light physics. Different corns ground through a common mill are known to have different grinding efficiencies (Hoffman et al., 2010). Corns with less extensive starch-protein matrixes (less vitreous) grind finer as compared with more vitreous corns (Hoffman et al., 2010). When particle size is decreased, the light scattering interface is increased, resulting in increased light reflection (Birth and Hecht, 1987). More simply, if corn grinds to a finer particle size, more light will be reflected (lower absorbance) because there are more particles to reflect light. In NIRS applications, variance in light reflection induced by particle size differentials in the sample is described as BLS (Hruschka, 1987).

The $\alpha-, \gamma-, \delta$-, and $\beta$-zein protein subunits of each HMC replicate at 0 (unfermented) and $240 \mathrm{~d}$ were profiled using HPLC by the procedures of Bietz (1983). 
Table 1. Nutrient composition and mean particle size of high-moisture corn (HMC) before ensiling (0 d)

\begin{tabular}{|c|c|c|c|c|c|c|}
\hline \multirow[b]{2}{*}{ Item } & \multicolumn{6}{|c|}{ Nutrient $^{1}$} \\
\hline & DM & $\mathrm{CP}$ & Starch & $\mathrm{ADF}$ & $\mathrm{NDF}$ & MPS, $\mu \mathrm{m}$ \\
\hline \multicolumn{7}{|l|}{ HMC A } \\
\hline Control & 74.4 & 9.0 & 69.1 & 2.3 & 8.1 & 1,017 \\
\hline Inoculated & 74.3 & 9.0 & 69.0 & 2.2 & 7.4 & 1,017 \\
\hline \multicolumn{7}{|l|}{ HMC B } \\
\hline Control & 70.8 & 8.1 & 65.5 & 2.4 & 8.0 & 815 \\
\hline Inoculated & 70.6 & 8.0 & 65.4 & \multirow{2}{*}{$P$-value } & 7.9 & 843 \\
\hline Main effect & & & & & & \\
\hline Inoculant & 0.16 & 0.36 & 0.33 & 0.07 & 0.10 & 0.33 \\
\hline HMC & $<0.001$ & $<0.001$ & $<0.001$ & 0.43 & 0.24 & $<0.001$ \\
\hline SEM & 0.16 & 0.03 & 0.25 & 0.09 & 0.15 & 19.8 \\
\hline
\end{tabular}

Corn was ground with a Udy mill (Udy Corporation, Boulder, CO) fit with a 1-mm screen. Alcohol-soluble proteins were extracted from $10 \mathrm{mg}$ of ground corn with $100 \mu \mathrm{L}$ of extraction buffer $(70 \% \mathrm{EtOH}, 61 \mathrm{mM}$ $\mathrm{NaOAc}, 5 \%$-mercaptoethanol). Ground corn and buffer were vortexed briefly, shaken at $37^{\circ} \mathrm{C}$ for $1 \mathrm{~h}$, and then centrifuged at $11,500 \times g$ for $10 \mathrm{~min}$. The supernatant was diluted 1:4 with extraction buffer. A $25-\mu \mathrm{L}$ aliquot of each extract was injected onto a $\mathrm{C} 18$ protein and peptide column at $55^{\circ} \mathrm{C}$ in a Waters 2695 Separation Module (Waters Corporation, Milford, MA), and absorbance of the eluate at $200 \mathrm{~nm}$ was measured with a Waters 2487 Dual Absorbance Detector (Waters Corporation). Separation of distinct proteins was achieved with a gradient of 45 to $75 \%$ acetonitrile with ultrapure water, both containing $0.01 \%$ trifluoroacetic acid, for $40 \mathrm{~min}$ of elution at a flow rate of $2 \mathrm{~mL} / \mathrm{min}$. Each chromatogram was integrated with Empower software (Waters Corporation) with a minimum unitless peak width of 30 and threshold of 800 to obtain the total area under all peaks and the area for each individual peak.

Each replicate at 0 (unfermented) and $240 \mathrm{~d}$ also was examined visually using scanning electron microscopy. A 12-mm electron microscopy aluminum stub holder was fitted with 12-mm double-sided carbon sticky tab. The stub was tipped onto a horizontal surface of dried 1-mm Udy ground HMC. Excess sample material was removed and material adhering to the tab was sputter-coated (Auto Conductavac IV, See Vac Inc., Pittsburgh, PA) with $30 \mathrm{~nm}$ of a gold-palladium alloy. Scanning electron micrographs were taken at 10,000 $\times$ magnification with a scanning electron microscope (Hitachi S-570, Tarrytown, NY).

\section{Statistics}

Data were evaluated as a split-split plot (Littell et al., 1996) using the PROC MIXED procedures of SAS
(SAS Institute, 2001). Random HMC (A and B) were defined as whole plots with ensiling time and inoculation as subplots. Main effects in the model included the HMC, inoculant, ensiling time, and their interactions. Random model effects included replication and interactions of replication with both HMC and inoculant. For HPLC analysis of $\alpha, \gamma, \delta$, and $\beta$ zein regions, unitless peak areas were converted (peak area $\times 10^{-5}$ ) to a unitless peak area index and ensiling times of 0 (unfermented) and $240 \mathrm{~d}$ were used in the model. Significant main effects or interactions were declared when $P<$ 0.05 .

\section{RESULTS}

The nutrient composition and MPS of HMC before ensiling $(0 \mathrm{~d})$ are listed in Table 1. High-moisture corn A was greater $(P<0.001)$ in DM, CP, and starch concentrations, but contained similar amounts of $\mathrm{ADF}(P$ $=0.43)$ and $\mathrm{NDF}(P=0.24)$ compared with HMC B. The MPS of HMC A was approximately $200 \mu \mathrm{m}$ greater $(P<0.001)$ than that observed for HMC B.

High-moisture corn origin and ensiling time altered $(P<0.05) \mathrm{pH}$, fermentation acids, protein fractions, and NIRS BLS of HMC (Table 2). Inoculation altered $(P<0.05) \mathrm{pH}$, fermentation acids, $\mathrm{NH}_{3}-\mathrm{N}$, and NIRS BLS, but had no effect $(P>0.05)$ on buffer SCP, PrOH $\mathrm{SCP}$, or ADICP. Because numerous interactions between HMC origin, ensiling time, and inoculation influenced $\mathrm{pH}$, fermentation acids, protein fractions, and NIRS BLS mean data are presented in graphic form for ease of interpretation. The $\mathrm{pH}$, lactate, and acetate contents of the HMC with and without inoculation across ensiling times are presented in Figure 1. No butyrate or propionate was detected in either HMC. The $\mathrm{pH}$ of HMC decreased with advancing ensiling time, but the decline in $\mathrm{pH}$ across ensiling time was less extensive for HMC A. Inoculation with $L$. buchneri reduced $\mathrm{pH}$ for both HMC A and B. Lactate and acetate contents of HMC 
Table 2. Statistical analysis of the influence of high-moisture corn (HMC) origin, ensiling time, and inoculation on fermentation, protein fractions, and near-infrared reflectance spectroscopy baseline shift (NIRS BLS) ${ }^{1}$

\begin{tabular}{|c|c|c|c|c|c|c|c|c|c|}
\hline \multirow[b]{2}{*}{ Item } & \multicolumn{3}{|c|}{ Fermentation } & \multicolumn{5}{|c|}{ Protein fraction $^{2}$} & \multirow[b]{2}{*}{$\begin{array}{l}\text { NIRS } \\
\text { BLS }^{3}\end{array}$} \\
\hline & $\mathrm{pH}$ & Lactate & Acetate & $\begin{array}{c}\mathrm{NH}_{3}-\mathrm{N} \\
\% \text { of total } \mathrm{N}\end{array}$ & $\begin{array}{l}\text { Buffer } \\
\text { SCP }\end{array}$ & $\begin{array}{l}\mathrm{PrOH} \\
\text { SCP }\end{array}$ & ADICP & NDICP & \\
\hline \multicolumn{10}{|l|}{ Main effect, $P$-value } \\
\hline Inoculant & $<0.001$ & $<0.01$ & $<0.001$ & $<0.001$ & 0.69 & 0.59 & 0.58 & 0.05 & 0.03 \\
\hline Time & $<0.001$ & $<0.001$ & $<0.001$ & $<0.001$ & $<0.001$ & 0.01 & $<0.001$ & $<0.001$ & $<0.001$ \\
\hline $\mathrm{HMC}$ & $<0.001$ & $<0.001$ & $<0.001$ & $<0.001$ & $<0.001$ & $<0.01$ & 0.02 & $<0.001$ & $<0.001$ \\
\hline HMC $\times$ inoculant & $<0.001$ & $<0.001$ & $<0.001$ & 0.04 & 0.17 & 0.29 & 0.36 & 0.24 & 0.68 \\
\hline $\mathrm{HMC} \times$ time & $<0.001$ & $<0.001$ & $<0.001$ & $<0.001$ & 0.06 & $<0.001$ & 0.01 & $<0.001$ & $<0.001$ \\
\hline HMC $\times$ inoculant $\times$ time & $<0.001$ & $<0.001$ & $<0.001$ & 0.37 & 0.12 & 0.13 & 0.34 & $<0.001$ & $<0.001$ \\
\hline SEM & 0.037 & 0.021 & 0.014 & 0.114 & 0.290 & 0.093 & 0.221 & 0.068 & 0.22 \\
\hline
\end{tabular}

${ }^{1}$ Values are on a DM basis unless otherwise specified.

${ }^{2} \mathrm{PrOH}=\mathrm{H}_{2} \mathrm{O}(44.4 \%)+$ isopropanol $(55.0 \%)+2$-mercaptoethanol $(0.6 \%)$; SCP $=$ soluble crude protein; ADICP = acid detergent-insoluble $\mathrm{CP} ; \mathrm{NDICP}=$ neutral detergent-insoluble CP.

${ }^{3}$ For NIRS BLS, the unit value is $\Sigma \log _{10}(1 / \mathrm{R})$ between 1,380 and $1,480 \mathrm{~nm}$, where $\mathrm{R}=$ reflectance.

increased with advancing ensiling time but HMC origin and inoculation greatly influenced lactate and acetate content. Generally, lactate and acetate concentrations were lower for HMC A than for HMC B, and the fermentation of HMC A produced virtually no acetate without inoculation. Inoculation with $L$. buchneri truncated lactate production in both HMC at approximately $15 \mathrm{~d}$ in favor of acetate production thereafter. Observed effects of L. buchneri on HMC fermentation were similar to those reported by Kung et al., (2007). Concentrations of $\mathrm{NH}_{3}-\mathrm{N}$ and buffer and $\mathrm{PrOH}$ SCP across the ensiling times are presented in Figure 2. The $\mathrm{NH}_{3}-\mathrm{N}$ content of HMC increased over the ensiling period $(240 \mathrm{~d})$ for $\mathrm{A}, \mathrm{AI}, \mathrm{B}$, and $\mathrm{BI}$. The increase in $\mathrm{NH}_{3}-\mathrm{N}$ was more extensive for HMC B than for HMC A, and for inoculated compared with uninoculated HMC. The $\mathrm{NH}_{3} \mathrm{~N}$ content of HMC increased, without abatement, for 240 d. The concentration of $\mathrm{NH}_{3}-\mathrm{N}$ in $\mathrm{HMC}$ appeared to be a function of the extent of fermentation; inoculated HMC B had lower $\mathrm{pH}$, greater concentration of lactate and acetate, and 5.2 times greater $\mathrm{NH}_{3}-\mathrm{N}$ content after $240 \mathrm{~d}$ of ensiling, than uninoculated HMC A.

The buffer SCP concentrations likewise increased over the ensiling period. Averaged over all treatments, a 2.3fold increase in the buffer SCP content of HMC from 0 to $240 \mathrm{~d}$ of ensiling was found. The buffer SCP of HMC was influenced $(P<0.001)$ by ensiling time and HMC origin, but not by inoculation $(P=0.69)$. Inoculation also did not affect $(P=0.59)$ the $\mathrm{PrOH}$ SCP content of HMC. The PrOH SCP content of HMC appeared primarily to be associated with HMC origin $(P<0.01)$. Ensiling decreased $(P<0.001) \mathrm{PrOH}$ concentrations within HMC B, but only after $120 \mathrm{~d}$ of fermentation.

The ADICP, NDICP, and NIR BLS of HMC across the ensiling times are presented in Figure 3. Averaged over all ensiling times, concentrations of ADICP within HMC A were greater $(P=0.02)$ than within HMC B. In addition, ADICP was affected by ensiling time, but responses across HMC were inconsistent, with interaction $(P=0.01)$ of main effects observed (Table 2). Generally, no clear biological inference could be made from these responses; ADICP within HMC A and B, with and without inoculation, appeared to decline during the initial $15 \mathrm{~d}$ of fermentation, but became unstable thereafter. Observed changes in NDICP content of HMC across the ensiling times also was also challenging to explain. The NDICP content of HMC B decreased from 0 to $240 \mathrm{~d}$ of ensiling, whereas the NDICP content of HMC A was virtually unchanged across the ensiling time. Inoculation had no effect on ADICP content $(P<$ $0.58)$ but decreased $(P=0.05)$ NDICP concentrations within each specific HMC.

The NIRS BLS of HMC A was greater at all ensiling times compared with that of HMC B. The BLS of HMC was moderately decreased $(P=0.03)$ by inoculation, but NIRS BLS of HMC A and HMC B decreased dramatically after 60 and $30 \mathrm{~d}$ of ensiling, respectively. Observed NIRS BLS decrease suggests that HMC became more malleable as ensiling time advanced.

The influence of ensiling time and inoculation on hydrophobic zein proteins in the endosperm of HMC is presented in Table 3. Inoculation had no effect $(P \geq$ 0.27 ) on decreasing any of the hydrophobic zein protein subunits in HMC. Likewise, interactions of inoculant with HMC origin or ensiling time were not observed $(P \geq 0.18)$ for zein protein subunits. As a result, mean values for all zein subunits were compressed into HMC origin by ensiling time means and are presented in Figure 4 to aid interpretation. 

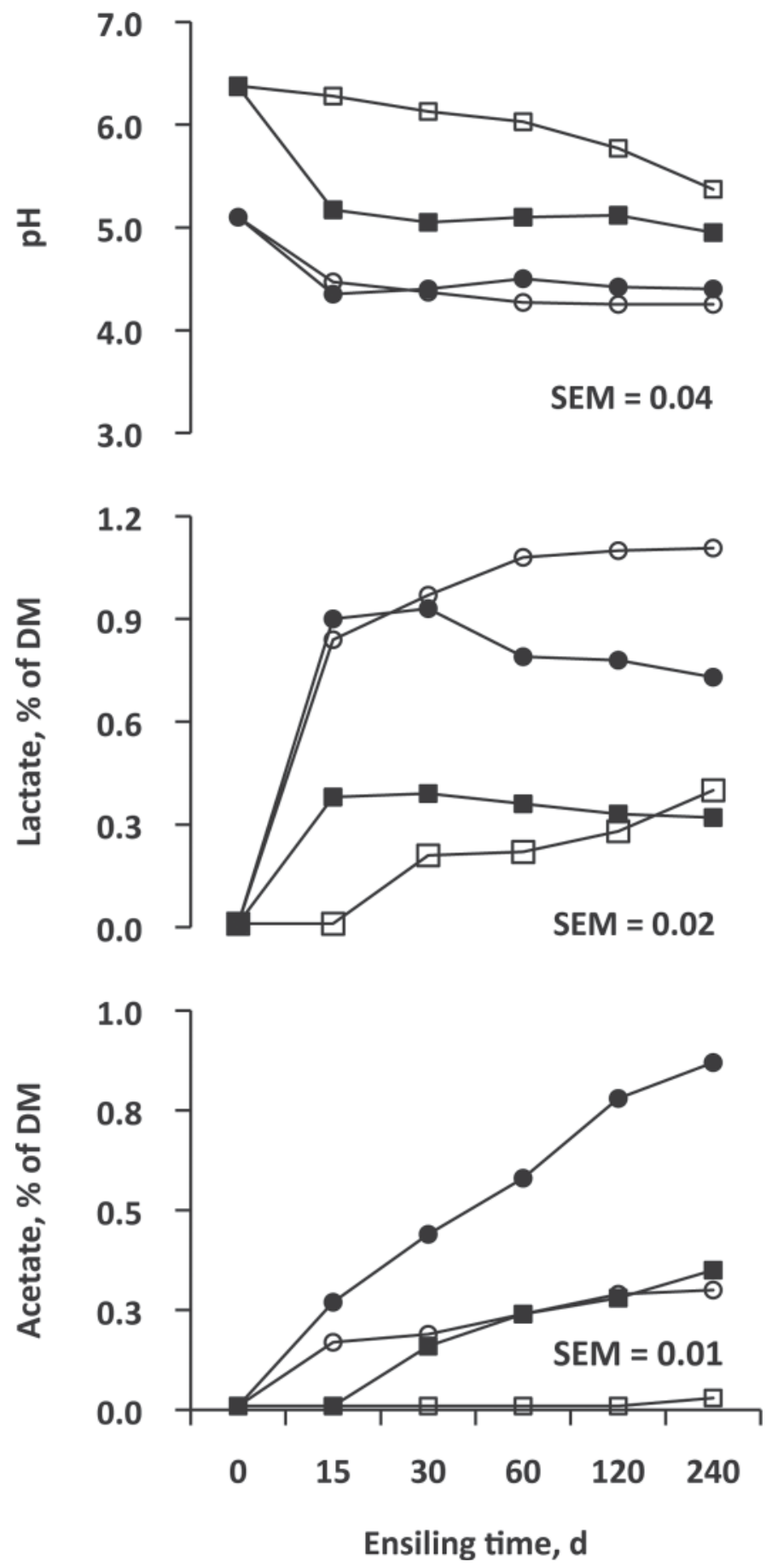

Figure 1. The $\mathrm{pH}$, lactate, and acetate contents of high-moisture corn (HMC) A ( $\square)$, HMC A + inoculant (ם), HMC B (O), and HMC $\mathrm{B}+$ inoculant $(\bullet)$ ensiled for $0,15,30,60,120$, and $240 \mathrm{~d}$.

At ensiling $(0 \mathrm{~d})$, HMC A contained more $(P<0.001)$ total $\alpha-, \beta-, \gamma$-, and $\delta$-zein proteins in the starch-protein matrix than did HMC B. These data support the observations of greater $\mathrm{CP}$ and $\mathrm{PrOH} \mathrm{SCP}$ concentrations within $\mathrm{HMC}$ A at ensiling ( $0 \mathrm{~d})$ than within $\mathrm{HMC} \mathrm{B}$
(Landry et al., 2000). For HMC A, ensiling for $240 \mathrm{~d}$ reduced all $8 \alpha$-zein and both $\gamma$-zein subunits. Total $\beta$ and $\delta$-zeins in HMC A were less extensively decreased after $240 \mathrm{~d}$ of ensiling. For HMC B, 5 of 8 subunits of $\alpha$, and all $\beta-, \gamma$, and $\delta$-zeins were decreased after ensiling for $240 \mathrm{~d}$. Ensiling for $240 \mathrm{~d}$ decreased $\gamma$-zeins (16 and $27 \mathrm{kDa}$ ) in HMC A and B more extensively than other zein protein subunits. Ensiling for $240 \mathrm{~d}$ decreased $\gamma$-zeins by 42.2 and $73.2 \%$ for HMC A and $\mathrm{B}$, respectively. The large decrease of $16-$ and $27-\mathrm{kDa}$ $\gamma$-zein proteins, induced by ensiling time, may have important implications pertaining to starch digestion in ruminants.

\section{DISCUSSION}

It is well recognized that ruminal degradation of HMC starch is more extensive than that of dry corn starch (Firkins et al., 2001). It has also been reported that rumen degradability of corn silage (Newbold et al., 2006), starch, and HMC DM (Benton et al., 2005) increases with ensiling time. It is frequently hypothesized that hydrophobic zein proteins, which form the starch-protein matrix, are degraded in the ensiling process (Philippeau and Michalet-Doreau, 1998; Jurjanz and Monteils, 2005), thereby allowing greater access to starch granules by rumen bacteria, but detailed evaluations of this hypothesis are limited.

Hydrophobic zein proteins in the starch-protein matrix could potentially be degraded in the ensiling process by solubilization or by proteolytic activity. Zein proteins are intensely hydrophobic and innately insoluble in water or rumen fluid, but are soluble in lactic and acetic acid (Lawton, 2002). Because fermentation yields lactic and acetic acid, hydrophobic zein proteins in the starch-protein matrix could simply be solubilized. Proteolysis also is an intrinsic mechanism in HMC fermentation, which induces degradation of proteins (Baron et al., 1986). Proteolysis is best defined as a joint degradation of proteins by active plant enzymes or bacterial proteases (Vierstra, 1996). Logically, hydrophobic zein proteins in the starch-protein matrix could be degraded by proteolytic activity in HMC.

Although this study was not specifically designed to differentiate mechanisms by which hydrophobic zein proteins in $\mathrm{HMC}$ are degraded, inferences from the study suggest that hydrophobic zein proteins are more likely degraded via proteolytic activity than by solubilization. Inoculating $\mathrm{HMC}$, in an attempt to alter fermentation acids, increased lactic and acetic acid concentrations $1.6 \times$ and $1.2 \times$, respectively in HMC A and B as compared with uninoculated HMC at $240 \mathrm{~d}$ of ensiling. Despite greater concentrations of lactic and acetic acid in inoculated $\mathrm{HMC}$, no evidence 

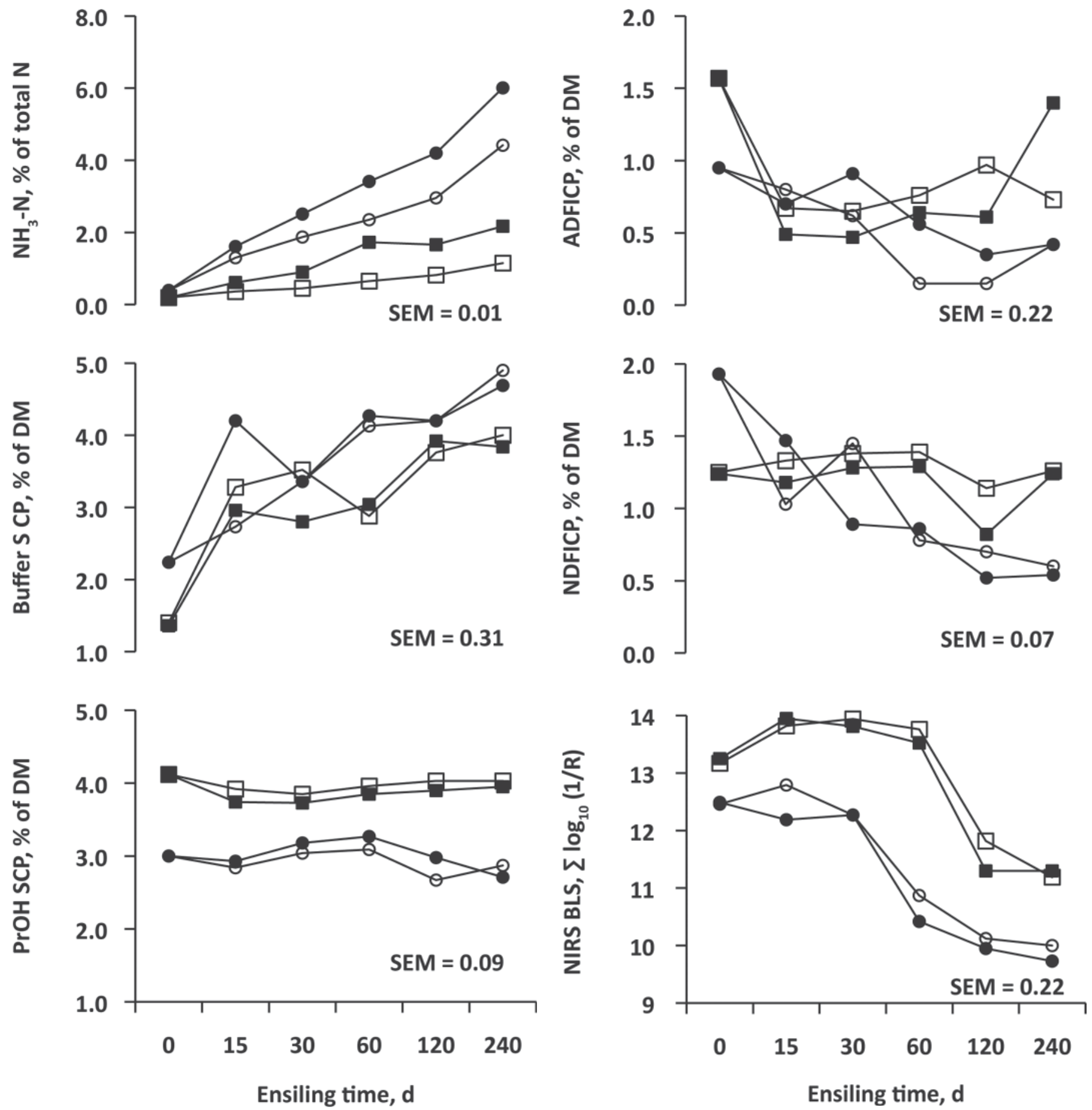

Figure 2. The $\mathrm{NH}_{3}-\mathrm{N}$, buffer-soluble crude protein (SCP), and isopropanol (PrOH) SCP contents of high-moisture corn (HMC) A ( $\square$ ), HMC A + inoculant (ם), HMC B (O), and HMC B + inoculant $(\bullet$ ensiled for $0,15,30,60,120$, and $240 \mathrm{~d}$.

that inoculation altered any subunit of $\alpha-, \beta-, \gamma-$, or $\delta$-zein protein was found. In contrast, ensiling $\mathrm{HMC}$ for $240 \mathrm{~d}$ decreased HPLC peak areas of most zein proteins. The reduction in zein proteins by proteolytic

Figure 3. The ADF-insoluble CP (ADFICP), NDF-insoluble CP (NDFICP), and near-infrared reflectance spectroscopy (NIRS) baseline shift (BLS) of high-moisture corn (HMC) A ( $\square$ ), HMC A + inoculant (ם), HMC B (O), and HMC B + inoculant $(\bullet)$ ensiled for 0, 15 $30,60,120$, and $240 \mathrm{~d}$. For NIRS BLS the unit value is $\Sigma \log _{10}(1 / \mathrm{R})$ between 1,380 and $1,480 \mathrm{~nm}$, where $\mathrm{R}=$ reflectance. 
activity is supported by $\mathrm{NH}_{3}-\mathrm{N}$ data. At ensiling (0 d), HMC did not contain any appreciable quantity of $\mathrm{NH}_{3}-\mathrm{N}$. However, the $\mathrm{NH}_{3}-\mathrm{N}$ concentrations increased steadily, without abatement, for $240 \mathrm{~d}$ for all HMC. In silages, $\mathrm{NH}_{3}-\mathrm{N}$ most often is defined as a product of bacterial deamination of amino acids, rather than a product of acid hydrolysis by silage VFA (Ohshima and McDonald, 1978). Similar to $\mathrm{NH}_{3}-\mathrm{N}$, buffer SCP in HMC was not influenced by inoculation, but buffer SCP also increased steadily, without abatement, for the 240-d ensiling period. Increasing the solubility of corn proteins in borate-phosphate buffer suggests that corn proteins became less hydrophobic with advancing ensiling time. Decreased hydrophobicity of corn proteins with advancing ensiling time should have resulted in a decrease in $\mathrm{PrOH} \mathrm{SCP}$ over the same time period. This effect was not observed, as PrOH SCP, while greater for HMC A than for HMC B, remained relatively constant across the ensiling times. This observation may be an assay nuance rather than a biological effect. The assay of Larson and Hoffman, (2008) was used to determine $\mathrm{PrOH}$ SCP, which is an estimate of total zein content. The assay quantifies total zein content using turbidity of hydrophobic proteins in TCA fit to a standard curve using purified zein. The effects of size $(\mathrm{kDa})$, as well as the relative hydrophobicity of proteins on subsequent turbidity in TCA, were not defined by Larson and Hoffman (2008); therefore, hydrophobic zein proteins could be degraded partially, but the resulting peptides could yield equivalent turbidity in TCA. In short, the assay of Larson and Hoffman (2008) appeared to be effective at defining origin differences in zein proteins, but was not effective in defining the degradation of zein proteins during fermentation. By contrast, the HPLC analysis appeared to clearly define origin differences, as well as degradation of zein proteins in ensiled HMC.

The ADICP and NDICP concentrations were determined to evaluate if these protein fractions provided any indirect evidence regarding the fate of hydrophobic zein proteins in HMC. It was challenging to make any indirect or logical biological linkages between ADICP and NDICP and the fate of hydrophobic zein proteins in the endosperm of HMC. The ADICP and NDICP concentrations in HMC were affected by ensiling time but responses across HMC origin and inoculation were inconsistent, with interactions of main effects observed. The lack of logical biological linkages between ADICP or NDICP and starch matrix proteins in HMC would be expected because ADICP and NDICP are assays developed for forages (Goering and VanSoest, 1970). In corn, ADF and NDF reside in the pericarp, and not in the endosperm, and hydrophobic proteins, not fiber, encapsulate starch in the endosperm. Therefore, ADICP and NDICP appeared to be ill-suited for mak-

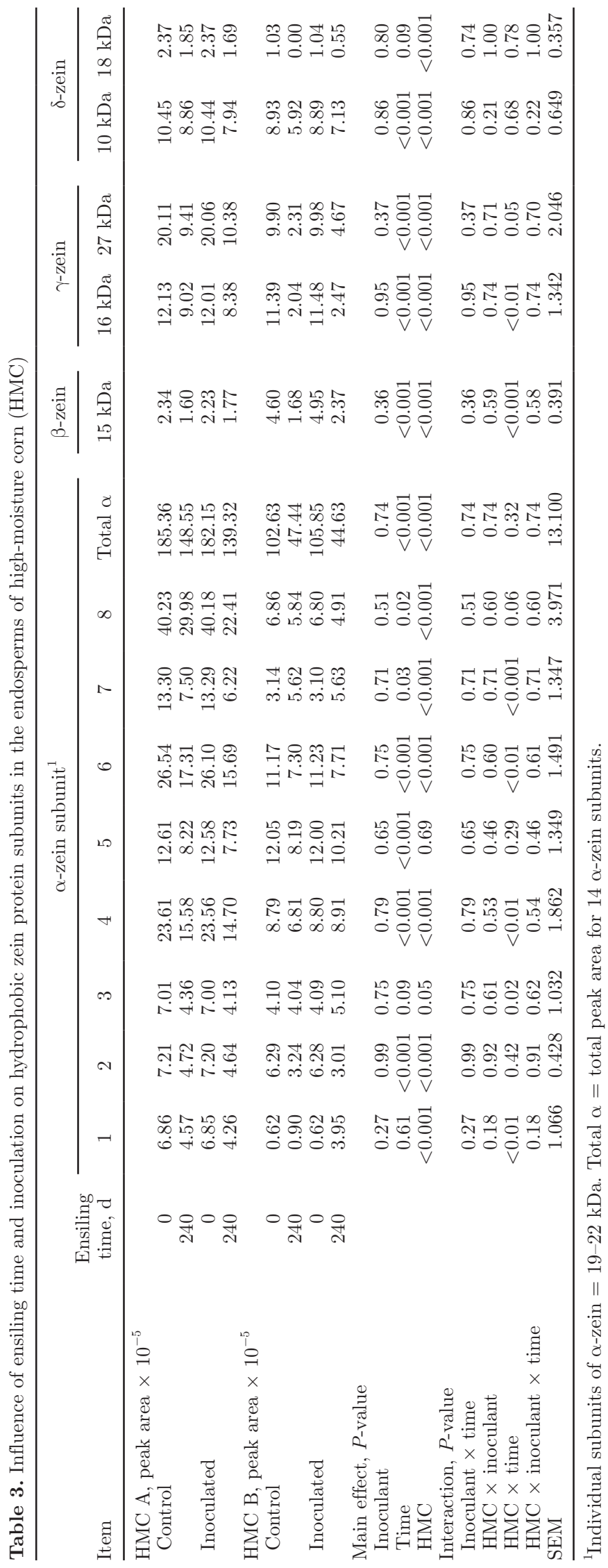

Journal of Dairy Science Vol. 94 No. 5, 2011 
ing indirect inferences with regard to starch digestibility in HMC.

Data from this study substantiates the hypothesis that hydrophobic zein proteins, especially $\gamma$-zeins, in the starch-protein matrix are degraded during the ensiling process as proposed by Philippeau and MichaletDoreau (1998) and Jurjanz and Monteils (2005). The $\gamma$-zeins lay peripheral to and cross-link with $\alpha$ - and $\delta$-zeins in the starch-protein matrix, thereby adhering starch granules together and ostensibly forming the starch-protein matrix (Buchanan et al., 2000; Mu-Forster and Wasserman, 1998). In dry corn, the primary difference between flint, dent, or less vitreous floury (fl2) or opaque (o2) corn endosperm types is the degree of starch granule cross-linking by $\gamma$-zein proteins. In dry corns, starch from floury (fl2) or opaque (o2) endosperm types has been shown to be more digestible by lactating dairy cows (Allen et al., 2008; Lopes et al., 2009). Data from this study suggest $\gamma$-zein cross-linking proteins are highly degraded in the HMC fermentation process.

The degradation of $\gamma$ and other zeins proteins responsible for cross-linking starch granules together should result in a disassociation of starch granules in HMC and allow greater access to starch granules by rumen bacteria. To assess whether starch granules in HMC do, in fact, disassociate as a result of ensiling and subsequent degradation of zein proteins, electron micrographs were produced of HMC A and B at 0 and $240 \mathrm{~d}$ of ensiling. Because inoculation of HMC was demonstrated to have no effect on the degradation of zein proteins, electron micrographs of HMC A and B without inoculation are presented in Figure 5.

Differences in the starch-protein matrix between HMC A and B before ensiling ( $0 \mathrm{~d})$ can be observed clearly. Starch granules in HMC A appear tightly adhered and protein bodies in the interspaces between starch granules are readily observed. In contrast, starch granules in HMC B before ensiling appear more loosely adhered and protein bodies between starch granules are less apparent. The electron micrographs of HMC A and $\mathrm{B}$ at $0 \mathrm{~d}$ visually support the greater $\mathrm{PrOH} \mathrm{SCP}$, NIRS BLS, and HPLC zein peak areas observed for HMC A as compared with B. After $240 \mathrm{~d}$ of ensiling, some disassociation of starch granules in HMC A can be observed, but the disassociation appears incomplete, as starch granule clusters are still visible. In contrast, a near complete disassociation of starch granule clusters in HMC B occurred after ensiling for $240 \mathrm{~d}$. In multiple other scanning electron micrographs of HMC B, evaluated after $240 \mathrm{~d}$ of ensiling, primarily individual starch granules were observed, with few starch granule clusters remaining. The complete (HMC B; 240-d) or incomplete (HMC A: 240-d) disassociation of starch granule clusters appears to be a function of the starch-
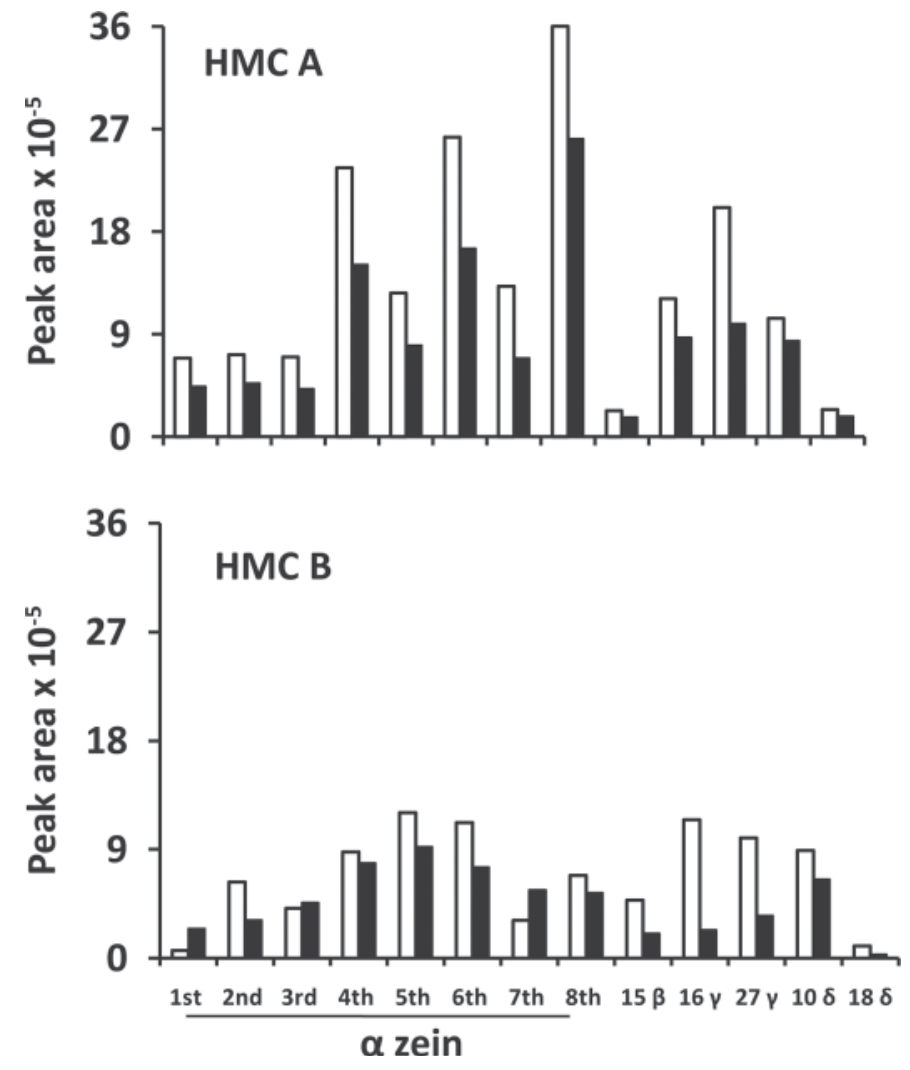

Figure 4. The HPLC peak area indexes (peak area $\times 10^{-5}$ ) of 8 $\alpha-(19-22 \mathrm{kDa})$ and $\beta-(15 \mathrm{kDa}), \gamma-(16$ and $27 \mathrm{kDa})$, and $\delta$ - (10 and $18 \mathrm{kDa}$ ) zein protein subunits of high-moisture corn (HMC) A and B ensiled for $0(\square)$ and $240(\square)$ d. Statistical inferences and SEM of individual zein protein subunits are presented in Table 3.

protein matrix origin (hybrid-maturity) and the extent of fermentation. By numerous measures in this study, the starch-protein matrix of HMC A was clearly more extensive than that of HMC B. By numerous measures, the fermentation of HMC A was less extensive than that of HMC B. The degree of starch encapsulation by hydrophobic zein proteins at ensiling, combined with fermentation intensity and length of the ensiling period, appear to be the determining factors regulating the relative disassociation of starch granule clusters in HMC.

\section{CONCLUSIONS}

It has been hypothesized that increased ruminal degradation of HMC starch by ruminants is related to fermentation and the degradation of hydrophobic zein proteins in the starch-protein matrix. Degradation of starch-matrix proteins in the ensiling process has likewise been hypothesized to allow for greater access to starch granules in HMC by rumen bacteria. In this study, we observed the 2 hypotheses to be ostensibly 
HMC A
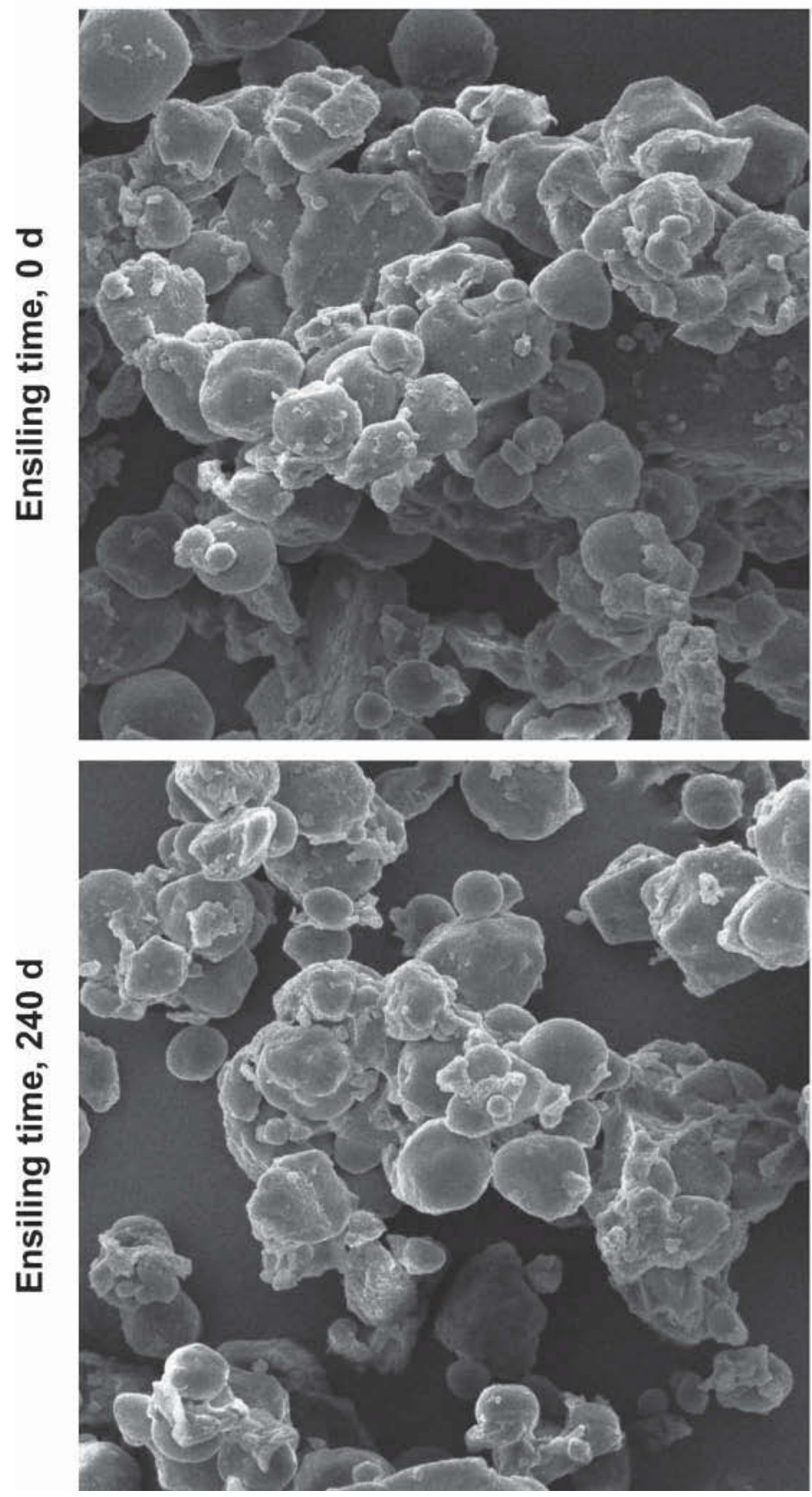

HMC B
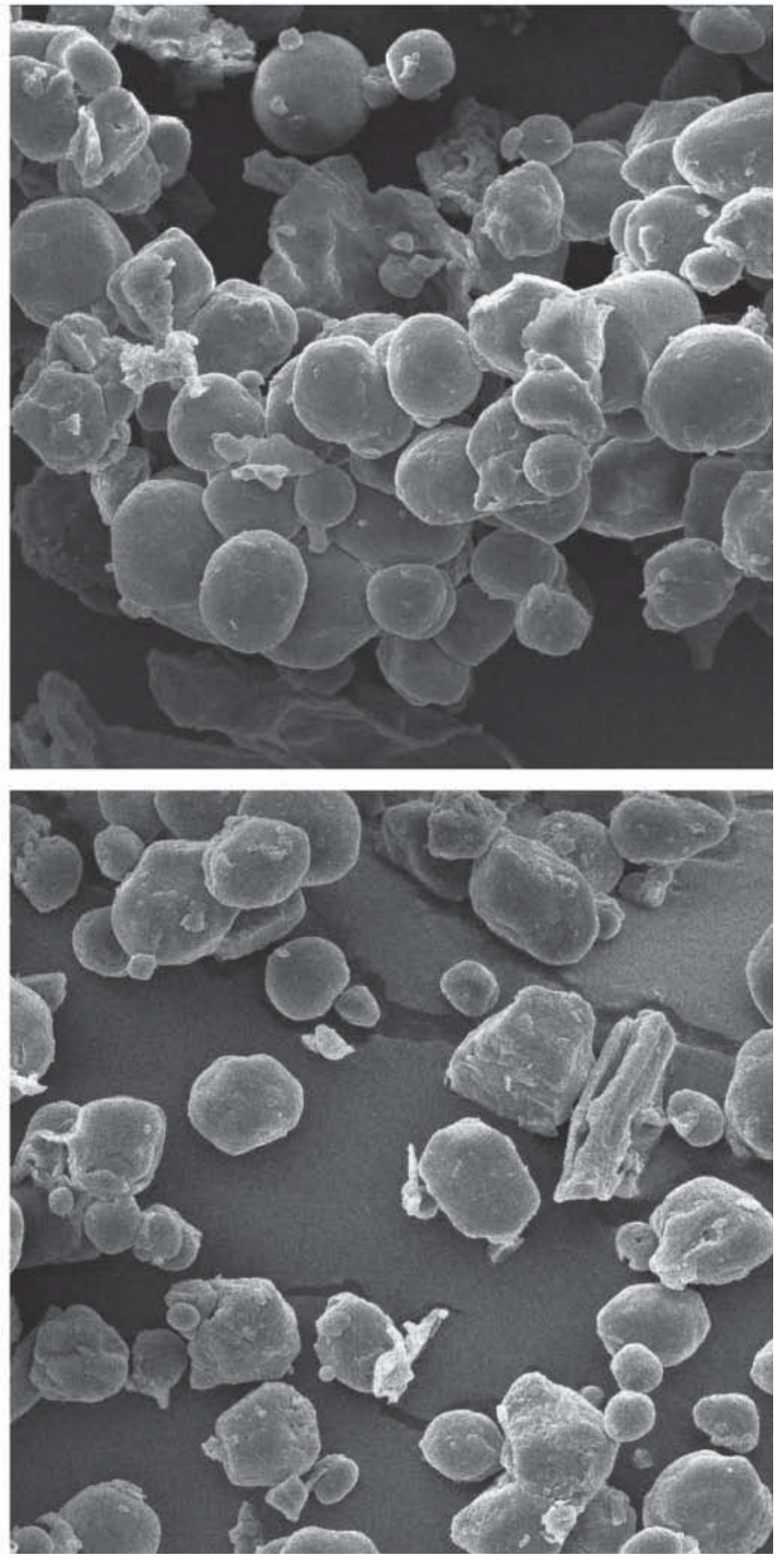

Figure 5. Scanning electron micrographs of high-moisture corn (HMC) A and B without inoculation ensiled for 0 and $240 \mathrm{~d}$.

correct. When random corn hybrids were ensiled over an extended period $(240 \mathrm{~d})$, hydrophobic zein proteins intrinsic to the starch protein matrix were substantially degraded, especially $\gamma$-zein proteins that cross-link starch granules together. Degradation of hydrophobic zein proteins in the ensiling process appears to be best explained by chronic proteolytic activity because inoculation, which yielded greater lactate and acetate concentrations in HMC, had no effect on the degradation of hydrophobic zein proteins in HMC. Scanning electron micrographs confirmed the disassociation of starch granule clusters in HMC, which would logically allow for greater access to starch granules in HMC by rumen bacteria 


\section{ACKNOWLEDGMENTS}

This project was financially supported through unrestricted gifts provided by Lallemand, Inc. and Bailey Consulting (Deforest, WI). The authors thank Magdalena Kurtz and James Bailey (Bailey Consulting) for their contributions and support of this project and Joe Heinz at the University of Wisconsin-Madison for his expertise in scanning electron microscopy.

\section{REFERENCES}

Allen, M. S., R. A. Longuski, and Y. Ying. 2008. Endosperm type of dry ground corn grain affects ruminal and total tract digestion of starch in lactating dairy cows. J. Dairy Sci. 91(Suppl.):529. (Abstr.)

AOAC. 1990. Official Methods of Analysis. 15th ed. Association of Official Analytical Chemists, Arlington, VA.

AOAC. 1998. Official Methods of Analysis. 16th ed., 4th rev. Association of Official Analytical Chemists, Gaithersburg, MD.

Baker, S., and T. Herrman. 2002. Evaluating particle size. MF-2051. Kansas State University Agricultural Experiment Station and Cooperative Extension Service, Manhattan, KS.

Baron, V. S., K. R. Stevenson, and J. G. Buchanan-Smith. 1986. Proteolysis and fermentation of corn-grain ensiled at several moisture levels and under several simulated storage methods. Can. J. Anim. Sci. 66:451-461.

Benton, J. R., T. Klopfenstein, and G. E. Erickson. 2005. Effects of corn moisture and length of ensiling on dry matter digestibility and rumen degradable protein. Nebraska Beef Cattle Reports: 31-33. University of Nebraska, Lincoln.

Bietz, J. A. 1983. Separation of cereal proteins by reversed-phase highperformance liquid chromatography. J. Chromatogr. 255:219 238.

Birth, G. S., and H. G. Hecht. 1987. The physics of near-infrared reflectance. Pages 1-16 in Near-Infrared Technology in the Agricultural and Food Industries. Am. Assoc. Cereal Chem., St. Paul, MN.

Buchanan, B. B., W. Gruissem, and R. L. Jones. 2000. Biochemistry and Molecular Biology of Plants. Am. Soc. Plant Physiol., Rockville, MD.

Coblentz, W. K., and P. C. Hoffman. 2009. Effects of spontaneous heating on fiber composition, fiber digestibility, and in situ disappearance kinetics of neutral detergent fiber for alfalfa-orchardgrass hays. J. Dairy Sci. 92:2875-2895.

Correa, C. E. S., R. D. Shaver, M. N. Pereira, J. G. Lauer, and K. Kohn. 2002. Relationship between corn vitreousness and ruminal in situ starch degradability. J. Dairy Sci. 85:3008-3012.

Ehrman, T. 1996. Determination of starch in biomass samples by chemical solubilization and enzymatic digestion. LAP-016. US Department of Energy, National Bioenergy Center, Washington, DC.

Firkins, J. L., M. L. Eastridge, N. R. St-Pierre, and S. M. Noftsger. 2001. Effects of grain variability and processing on starch utilization by lactating dairy cattle. J. Anim. Sci. 79(E. Suppl.):E218E238.

Goering, H. K., and P. J. Van Soest. 1970. Pages 8-11 in Forage Fiber Analyses (Apparatus, Reagents, Procedures, and Some Applications). Agric. Handbook No. 379. ARS-USDA, Washington, DC.

Hamaker, B. R., A. A. Mohamed, J. E. Habben, C. P. Huang, and B. A. Larkins. 1995. Efficient procedure for extracting maize and sorghum kernel proteins reveals higher prolamin contents than the conventional method. Cereal Chem. 72:583-588.

Hoffman, P. C., D. Ngonyamo-Majee, and R. D. Shaver. 2010. Determination of corn hardness in diverse corn germplasm using near- infrared reflectance baseline shift as a measure of grinding resistance. J. Dairy Sci. 93:1685-1689.

Hruschka, W. R. 1987. Data analysis: Wavelength selection methods. Pages 35-53 in Near-Infrared Technology in the Agricultural and Food Industries. Am. Assoc. Cereal Chem., St. Paul, MN.

Jurjanz, S., and V. Monteils. 2005. Ruminal degradability of corn forages depending on the processing method employed. Anim. Res. $3: 15-23$.

Krishnamoorthy, U., C. J. Sniffen, M. D. Stern, and P. J. Van Soest. 1983. Evaluation of a rumen mathematical model and in vitro simulated proteolysis to estimate the rumen-undegraded nitrogen content of feedstuffs. Br. J. Nutr. 50:555-568.

Kung, L., R. J. Schmidt, T. E. Ebling, and W. Hu. 2007. The effect of Lactobacillus buchneri 40788 on the fermentation and aerobic stability of ground and whole high-moisture corn. J. Dairy Sci. 90:2309-2314

Landry, J., S. Delhaye, and C. Damerval. 2000. Improved method for isolating and quantitating $\alpha$-amino nitrogen as nonprotein, true protein, salt-soluble proteins, zeins, and true glutelins in maize endosperm. Cereal Chem. 77:620-626.

Larson, J., and P. C. Hoffman. 2008. A method to quantify prolamin proteins in corn that are negatively related to starch digestibility in ruminants. J. Dairy Sci. 91:4834-4839.

Lawton, J. W. 2002. Zein: A history of processing and use. Cereal Chem. 79:1-18.

Littell, R. C., G. A. Milliken, W. W. Stroup, and R. D. Wolfinger. 1996. SAS System for Mixed Models. SAS Institute Inc., Cary, NC.

Lopes, J. C., R. D. Shaver, P. C. Hoffman, M. S. Akins, S. J. Bertics, H. Gencoglu, and J. G. Coors. 2009. Type of corn endosperm influences nutrient digestibility in lactating dairy cows. J. Dairy Sci. 92:4541-4548.

Mertens, D. R. 1992. Critical conditions in determining detergent fibers. Page C-1 in Proc. Natl. Forage Testing Assoc. Forage Anal Workshop, Denver, CO. Natl. Forage Testing Assoc., Omaha, NE.

Mu-Forster, C., and B. P. Wasserman. 1998. Surface localization of zein storage proteins in starch granules from maize endosperm: Proteolytic removal by thermolysin and in vitro cross-linking of granule-associated polypeptides. Plant Physiol. 116:1563-1571.

Muck, R. E., and J. T. Dickerson. 1988. Storage temperature effects on proteolysis in alfalfa silage. Trans. ASABE 31:1005-1009.

Newbold, J. R., E. A. Lewis, J. Lavrijssen, H. J. Brand, H. Vedder, and J. Bakker. 2006. Effect of storage time on ruminal starch degradability in corn silage. J. Dairy Sci. 89(Suppl. 1):190. (Abstr.)

Ngonyamo-Majee, D., R. D. Shaver, J. G. Coors, D. Sapienza, and J. G. Lauer. 2008. Relationship between kernel vitreousness and dry matter degradability for diverse corn germplasm. II. Ruminal and post-ruminal degradabilities. Anim. Feed Sci. Technol. 142:259-274.

Ohshima, M., and P. McDonald. 1978. A review of the changes in nitrogenous compounds of herbage during ensilage. J. Sci. Food Agric. 29:497-505.

Owens, F. N., R. A. Zinn, and Y. K. Kim. 1986. Limits to starch digestion in the ruminant small intestine. J. Anim. Sci. 63:16341648 .

Philippeau, C., J. Landry, and B. Michalet-Doreau. 2000. Influence of the protein distribution of maize endosperm on ruminal starch degradability. J. Sci. Food Agric. 80:404-408.

Philippeau, C., and B. Michalet-Doreau. 1998. Influence of genotype and ensiling of corn grain on in situ degradation of starch in the rumen. J. Dairy Sci. 81:2178-2184.

SAS Institute. 2001. SAS User's Guide: Statistics. SAS Inst. Inc. Cary, NC.

Van Soest, P. J., J. B. Robertson, and B. A. Lewis. 1991. Methods for dietary fiber, neutral detergent fiber, and nonstarch polysaccharides in relation to animal nutrition. J. Dairy Sci. 74:3583-3597.

Vierstra, R. D. 1996. Proteolysis in plants: Mechanisms and functions. Plant Mol. Biol. 32:275-302. 